\title{
Pemanfaatan Media Sosial Dikalangan Usaha Kecil Dan Menengah (UKM) Keramik Sentra Industri Keramik Plered Kabupaten Purwakarta
}

\author{
${ }^{1}$ Poppy Ruliana, ${ }^{2}$ Irwansyah, ${ }^{3}$ Suhendra Atmaja, ${ }^{4}$ Soebiagdo, ${ }^{5}$ Riyanto \\ ${ }^{1,2,3,4}$ LPPM STIKOM InterStudi
}

\begin{abstract}
ABSTRAK
\section{Pendahuluan}

Industri bisnis kerajinan keramik di Sentra Industri Keramik Plered Kabupaten Purwakarta telah ada sejak dulu telah mengenal kerajinan tanah liat sebagai bagian dari sejarah serta budaya masyarakat setempat. Jika dilihat dari sejarahnya, kerajinan tanah liat dapat disangkut-pautkan dengan karya seni ataupun sebagai alat perkakas rumah tangga. Dapat dikatakan sejak zaman dahulu tanah liat disebutkan sebagai karya seni tertua yang pernah ada ${ }^{1}$. Namun kerajinan tanah liat memiliki beragam definisi, banyak yang mengatakan bahwa benda-benda yang dibuat dari tanah liat dari awal kemunculannya benda tersebut dinamakan dengan keramik. Beragam bentuk dari kerajinan tanah liat atau sebutan lain yaitu keramik, sudah berkembang sedemikian rupa, seperti gerabah, tembikar, porselen dan lainlain.

Bisnis kerajinan keramik yang dilakukan oleh para UKM (Usaha Kecil Menengah) keramik awalnya telah mengalami perkembangan yang baik, akan tetapi karena keterbatasan dalam mempromosikan dan juga karena perkembangan teknologi dan lnformasi yang kita kenal sebagai era digital dan desain serta factor sumber daya manusia maka perkembangan kerajinan keramik mengalami penurunan yang cukup tajam dari jumlah UKM keramik yang ada. Di samping banyaknya peluang yang ada, industri kecil atau industri kerajinan masih memiliki banyak kekurangan. Menurut Pelham (1999) industri kecil

masih lemah dalam perencanaan, pemikiran strategis dan pandangan jangka panjang. Kecenderungan tersebut, mengakibatkan para pengrajin kesulitan dengan mengatasi persaingan pasar di Indonesia. Hal tersebut disebabkan kurangnya informasi yang mereka terima dan pengrajin belum memposisikan diri sebagai wirausaha yang berkualitas, serta kreativitas untuk menghadapi persaingan belum optimal. Oleh karena itu kualitas perilaku pengrajin masih rendah (Utami, 2007).

Pengrajin keramik sebagai peasant memiliki skala produksi yang kecil, karena menggunakan teknologi yang relatif sederhana. Hal ini membuat asumsi-asumsi tentang sistem ekonomi peasant diatas kuat atas pengrajin. Asumsi-asumsi tersebut dibuktikan dengan pernyataan dari Firth (1950: 504510) dimana sistem ekonomi peasant adalah sistem yang pekerjanya menggunakan teknologi dan ketrampilan sederhana. Dengan banyaknya literatur yang meneliti tentang penyuluhan pengrajin usaha keramik membuktikan bahwa para pengrajin keramik masih sederhana dalam proses produksinya. Pengaruh pendidikan misalnya, dalam melakukan usaha kerajinan merupakan hal yang penting. Pendidikan dalam berwirausaha akan mengembangkan upaya mereka serta meningkatkan kompetensi untuk keberhasilan usaha. Sejalan dengan pernyataan Perry, Batstone, dan Pulsarum (2003) semakin lama seseorang menempuh pendidikan maka semakin besar kesuksesan yang dapat diraih. Pendidikan formal
\end{abstract}


misalnya, ditujukan untuk memperkuat dan mendorong kreatifitas, keingintahuan, sifat terbuka dan ketrampilan seseorang. Dari pendidikan formal ini akan berkontribusi pada kemampuan seseorang pelaku wirausaha dalam kerajinan keramik dalam mengenlola sumberdaya kehidupannya (Utami, 2007), serta ditambah dengan pelatihan teknis dan usaha untuk menggunakan teknologi dan produksi yang maju. Jelas dengan tingkat pendidikan yang rendah akan memberikan hambatan atau kesulitan bagi pelaku usaha pengrajin keramik di Plered untuk meningkatkan usahanya.

Untuk pengaruh yang terakhir, pengaruh komunikasi berperan untuk mempengaruhi pelaku usaha pengrajin keramik dengan pihak lain yang bersangkutan. Dalam hal ini akan menciptakan interaksi sosial dan mengakibatkan kegiatan komunikasi. Menurut Lionberger (dalam Utami, 2007) kegiatan komunikasi ini akan menciptakan golongan inovatif, biasanya banyak memanfaatkan beragam sumber informasi, seperti lembaga pendidikan, lembaga penelitian, dinas-dinas yang terkait, media massa, tokoh-tokoh masyarakat, sesama pengrajin atau lembaga komersial (pedagang). Walaupun demikian, hal tersebut masih sulit masuk ke dalam dunia usaha kerajinan keramik. pengrajin keramik erat hubungannya dengan tetap melihat aspek sosial dalam mereka bekerja (Insania, 2011: 77). Dengan kemajuan teknologi pada saat ini, akses untuk mendapatkan informasi dengan cepat bukan hal yang sulit tetapi terhambat pada kurangnya kompetensi pelaku usaha kerajinan keramik.

\section{Tujuan}

1. Menambah pengetahuan dan kemampuan dalam menyusun strategi promosi dalam memasarkan produk keramik dan mengaplikasikan desain komunikasi visual produk keramik sehingga menarik dan dapat dijadikan sebagai nilai jual bagi para pengusaha UKM keramik di Sentra Industri keramik Plered

2. Membantu pihak pemerintahan Desa Anjun dan UPT Keramik Purwakarta dalam meningkatkan kemampuan dan keterampilan para pengusaha UKM keramik guna mewujudkan meningkatkan branding produksi keramik dimata khalayak atau konsumen yang dijadikan sasaran

3. Memberikan pemahaman dan pengertian serta kemampuan pendekatan dengan komunikasi budaya dalam bentuk fungsi dan makna sehingga dapat meningkatkan mutu dan marketing dalam memasarkan produk keramik khas Plered

\section{Tinjauan Literatur}

\section{Komunikasi Bisnis}

Kemajuan ilmu pengetahuan dan teknologi mendorong perilaku manusia dalam memenuhi kebutuhan hidupnya. Akibatnya, saat ini kompetisi semakin kuat karena keterbatasan sumberdaya, sedangkan kebutuhan manusia semakin banyak meningkat.Karena itu sangat diperlukan strategi yang tepat untuk menciptakan hubungan dengan orang lain, klien, dan organisasi baik itu privat maupun publik.

Menurut Philip Kolter komunikasi bisnis adalah suatu kegiatan manusia yang ditujukan untuk memuaskan kebutuhan dan keinginan melalui peroses pertukaran. Sedangkan menurut Cutris komunikasi bisnis adalah komunikasi yang terdapat dalam organisasi bisnis dalam pertunjukan untuk memecahkan masalah dan membuat keputusan. Menurut posisi 
yang lebih tinggi dalam bisnis, ia semakin bergantung terhadap keahlian orang lain untuk membuat keputusan dan memecahkan masalah.

https://alihamdan.id/komunikasi-bisnis/

\section{Tujuan Komunikasi Bisnis}

Ada 3 tujuan utama dalam komunikasi bisnis yaitu: Memberi informasi, persuasi, dan melakukan kolaborasi dengan pelanggan. Berikut penjelasannya.

1. Memberi Informasi (Informing) Memberikan informasi seputar dunia bisnis terhadap pihak lain. Contoh, jika seorang pimpinan perusahaan ingin memperoleh pegawai yang diharapkan, maka ia akan memasang iklan melalui media.

Dalam hal ini terdapat kelebihan dan kekurangan pada setiap media, oleh karena itu harus pintar-pintar memilih mana media yang paling tepat.

2. Memberi Persuasi (Persuading)

Persuasi diberikan kepada pihak lain agar apa yang disampaikan bisa dipahami dengan benar. Hal seperti ini sering dilakukan terutama pada hubungan akan penegasan konfirmasi pesanan pelanggan, dengan tujuan supaya kedua belah pihak mendapatkan tidak ada yang dirugikan dan mendapatkan manfaatnya.

3. Melakukan Kolaborasi (Collaborating)

Bekerja sama dengan pihak lain atau yang biasa disebut dengan kolaborasi ini memudahkan seseorang dalam melakukan kerja sama bisnis.

Seiring dengan pesatnya kemajuan teknologi komunikasi, seseorang bisa menggunakan berbagai macam media telekomunikasi seperti telepon seluler dan media sosial dll. Teknologi komunikasi sangatlah penting untuk mempererat dalam kerja sama bisnis.

\section{Unsur-unsur Komunikasi}

Terdapat 6 unsur pokok dalam komunikasi yaitu:

1. Mempunyai tujuan.

2. Pertukaran, dalam hal ini melibatkan setidaknya 2 orang komunikator dan komunikan.

3. Informasi, gagasan, opini, dan intruksi merupakan isi dari pesan yang bentuknya sangat beragam, tergantung situasi, kondisi, dan tujuan.

4. Memakai saluran personal maupun impersonal yang mungkin bersifat tatap muka, memakai media tertentu atau media yang mampu menjangkau jutaan orang secara bersamaan.

5. Menggunakan simbol atau sinyal yang merupakan alat metode yang bisa dimengerti dan dipahami oleh penerima.

6. Pencapaian tujuan organisasi, salah satu karakteristik / ciri khas yang membedakan organisasi atau lembaga formal dar

\section{Bentuk Komunikasi Bisnis}

\section{Komunikasi Verbal}

Komunikasi verbal merupakan salah satu bentuk komunikasi yang disampaikan kepada pihak lain melalui tulisan dan tulisan. Seperti contoh ketika kita membaca surat kabar atau majalah, presentasi dan sebagainya. Komunikasi verbal ini terdapat 2 tipe yang berbeda berdasarkan aktif atau pasifnya peserta komunikasi dalam proses komunikasi. Dimana komunikasi verbal bisa bertindak sebagai komunikator atau pengirim pesan bisa juga bertindak sebagai audience. Berkomunikasi secara 
verbal dibutuhkan juga persiapan apa yang ingin diungkapkan menyusun dalam suatu pola yang berarti, baik dalam bentuk tulisan atau lisan seperti:

\section{a. Berbicara dan Menulis}

Suatu pesan penting dan kompleks, akan lebih baik apabila disampaikan dengan menggunakan tulisan, seperti surat, memo, dan laporan.

b. Mendengarkan dan Menulis

Guna mendapatkan komunikasi yang efektif, maka diperlukan komunikasi 2 arah di mana orang-orang yang terlibat di dalamnya memerlukan keterampilan mendengarakan dan membaca.

\section{Komunikasi Non-Verbal}

Dalam komunikasi bisnis, komunikasi nonverbal merupakan bentuk komunikasi yang paling mendasar. Walaupun komunikasi nonverbal mempunyai sifat yang kurang terstruktur sehingga sulit untuk dipelajari.

Seperti memahami ekspresi wajah, simbol-simbol, gerakan tubuh, sandi, warna, dan intonasi. Dalam penyampaian komunikasi ini biasanya dilakukan secara spontan tanpa ada rencana dan terkadang dalam melakukannya tidak sadar.

Beberapa tujuan komunikasi nonverbal ialah:

1. Mengekspresikan emosi.

2. Mengatur alur suatu percakapan.

3. Menyediakan dan memberikan informasi.

4. Mengendalikan atau memengaruhi orang lain.

5. Memberi sifat dan melengkapi, menentang atau mengembangkan pesan-pesan verbal.

6. Mempermudah tugas-tugas khusus.
Terkadang dalam prakteknya
terdapat penggabungan komunikasi verbal dan nonverbal. Karena terkadang kata-kata yang disampaikan dalam suatu komunikasi hanya membawa sebagian dari pesan saja. https://alihamdan.id/komunikasi

\section{Media Sosial dalam Bisnis}

Media sosial adalah sebuah media daring, dengan para penggunanya bisa dengan mudah berpartisipasi, berbagi, dan menciptakan isi meliputi blog, jejaring sosial, wiki, forum dan dunia virtual. Blog, jejaring sosial dan wiki merupakan bentuk media sosial yang paling umum digunakan oleh masyarakat di seluruh dunia.

Andreas Kaplan dan Michael Haenlein mendefinisikan media sosial sebagai "sebuah kelompok aplikasi berbasis internet yang membangun di atas dasar ideologi dan teknologi Web 2.0, dan memungkinkan penciptaan dan pertukaran user-generated content

\section{Klasifikasi Media Sosial}

Media sosial teknologi mengambil berbagai bentuk termasuk majalah, forum internet, weblog, blog sosial, microblogging, wiki, podcast, foto atau gambar, video, peringkat dan bookmark sosial. Dengan menerapkan satu set teori-teori dalam bidang media penelitian (kehadiran sosial, media kekayaan) dan proses sosial (selfpresentasi, self-disclosure) Kaplan dan Haenlein menciptakan skema klasifikasi untuk berbagai jenis media sosial dalam artikel Horizons Bisnis mereka diterbitkan dalam 2010. Menurut Kaplan dan Haenlein ada enam jenis media sosial

\section{a. Proyek kolaborasi}

Situs web mengizinkan usernya untuk dapat mengubah, menambah, ataupun menghapus konten-konten yang ada di situs web ini. Contohnya wikipedia. 


\section{b. Blog dan microblog}

User lebih bebas dalam mengekspresikan sesuatu di blog ini seperti curhat ataupun mengkritik kebijakan pemerintah. Contohnya Twitter.

\section{c. Konten}

para user dari pengguna situs web ini saling meng-share konten-konten media, baik seperti video, ebook, gambar, dan lain-lain. Contohnya YouTube

\section{d. Situs jejaring sosial}

Aplikasi yang mengizinkan user untuk dapat terhubung dengan cara membuat informasi pribadi sehingga dapat terhubung dengan orang lain. Informasi pribadi itu bisa seperti foto-foto. contoh facebook

\section{e. Virtual game world}

Dunia virtual, di mana mengreplikasikan lingkungan $3 \mathrm{D}$, di mana user bisa muncul dalam bentuk avatar-avatar yang diinginkan serta berinteraksi dengan orang lain selayaknya di dunia nyata. Contohnya gim daring.

\section{f. Virtual social world}

Dunia virtual yang di mana penggunanya merasa hidup di dunia virtual, sama seperti virtual game world, berinteraksi dengan yang lain. Namun, Virtual Social World lebih bebas, dan lebih ke arah kehidupan, contohnya second life.

\section{Gambar 1. Jejaring media social}

Sumber :

https://www.google.co.id/search?q=ga $\underline{\text { mbar+ilustrasi+media+sosial\&saf }}$

Menurut Kietzmann, Jan $\mathrm{H}$. (2011). Perkembangan dari media sosial ini sungguh pesat, ini bisa di lihat dari banyaknya jumlah anggota yang di miliki masing-masing situs jejaring sosial ini,berikut tabel jumlah anggota dari masing-masing situs per Agustus 2017.

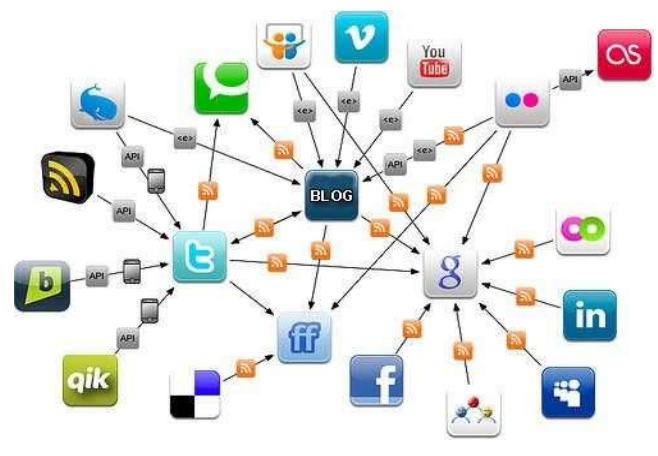

Tabel 1. tabel jumlah anggota dari masing-masing situs per Agustus 2017

\begin{tabular}{|l|l|l|}
\hline No & Nama situs & $\begin{array}{l}\text { Jumlah } \\
\text { member }\end{array}$ \\
\hline 1 & $\underline{\text { Facebook }}$ & 2.047 .000 .000 \\
\hline 2 & $\underline{\text { Youtube }}$ & 1.500 .000 .000 \\
\hline 3 & $\underline{\text { WhatsApp }}$ & 1.200 .000 .000 \\
\hline 4 & $\begin{array}{l}\text { Facebook } \\
\text { Messenger }\end{array}$ & 1.200 .000 .000 \\
\hline 5 & $\underline{\text { WeChat }}$ & 938.000 .000 \\
\hline 6 & $\underline{\text { QQ }}$ & 861.000 .000 \\
\hline 7 & $\underline{\text { Instagram }}$ & 700.000 .000 \\
\hline 8 & $\underline{\text { Qzone }}$ & 638.000 .000 \\
\hline 9 & $\underline{\text { Tumblr }}$ & 357.000 .000 \\
\hline 10 & $\underline{\text { Twitter }}$ & 328.000 .000 \\
\hline 11 & $\underline{\text { Sina Weibo }}$ & 313.000 .000 \\
\hline 12 & Baidu Tieba & 300.000 .000 \\
\hline 13 & $\underline{\text { Skype }}$ & 300.000 .000 \\
\hline 14 & $\underline{\text { Viber }}$ & 260.000 .000 \\
\hline 15 & $\underline{\text { Snapchat }}$ & 255.000 .000 \\
\hline 16 & $\underline{\text { Reddit }}$ & 250.000 .000 \\
\hline 17 & $\underline{\text { LINE }}$ & 214.000 .000 \\
\hline 18 & $\underline{\text { Pinterest }}$ & 175.000 .000 \\
\hline
\end{tabular}

\section{Ciri-Ciri Media Sosia}

- Pesan yang di sampaikan tidak hanya untuk satu orang saja namun bisa keberbagai banyak orang contohnya pesan melalui SMS ataupun internet 
- Pesan yang di sampaikan bebas, tanpa harus melalui suatu Gatekeeper

- Pesan yang di sampaikan cenderung lebih cepat di banding media lainnya

- Penerima pesan yang menentukan waktu interaksi

\section{Manfaat Media Sosial untuk Bisnis}

Seperti yang sudah disinggung pada pengertian manajemen media sosial di atas, ada beberapa hal yang menjadi alasan pentingnya mengelola media social dalam perkembangan bisnis yaitu diantaranya:

\section{a. Mengenal pelanggan}

Kesuksesan sebuah bisnis tidak terlepas dari keberadaan pelanggan. Dengan memaksimalkan media sosial bisa membantu Anda mengenal pelanggan lebih dekat. Media sosial bisa dijadikan alat survey untuk memetakan konsumen seperti apa yang menjadi pelanggan Anda.

Misalnya Anda bisa menggunakan tool seperti Facebook Insight untuk mempelajari dominansi pelanggan Anda berdasarkan usia dan jenis kelamin. Informasi seperti ini bermanfaat untuk memaksimalkan promosi dan branding.

\section{b. Mendengar keinginan}

\section{konsumen}

Adanya feedback baik positif maupu negatif dari konsumen Anda bisa membantu untuk mengevaluasi bisnis Anda menjadi lebih baik. Melalui media sosial seperti situs resmi perusahaan atau media sosial bisa lebih cepat mendapatkan kritik atau saran dari konsumen. Sehingga media social bisa menjadi alat untuk mengukur kepuasan pelanggan Anda.

c. Memberikan respon cepat Dengan adanya testimoni pelanggan melalui media sosial maka Anda bisa memberikan respon secara lebih cepat. Perusahaan yang baik tidak hanya merespon keluhan via telepon saja, namun juga menerima keluhan melalui media sosial yang disediakan perusahaan.

d. Melihat persaingan di pasar Media sosial juga berperan untuk menggali informasi tentang kondisi pasar terutama dalam hal persaingan. Melalui media sosial Anda bisa mengumpulkan informasi tentang kelebihan dan kekurangan kompetitor Anda untuk meningkatkan strategi bisnis.

e. Meningkatkan pengunjung situs

Manajemen media sosial diperlukan untuk meningkatkan pengunjung situs atau website perusahaan. Manajemen bisa dilakukan dengan memasukkan konten yang dapat meningkatkan traffic SEO sehingga website bisnis bisa menjadi tranding di mesin pencari Google.

\section{Metode Pelaksanaan}

Khalayak sasaran yang dianggap satrategis dalam kegiatan ini adalah para UKM keramik yang berada di Sentra Industri Keramik, Plered Kabupaten Purwakarta yang memiliki kemampuan mengoperasikan komputer dan internet yang tidak sama, ada yang sudah mampu ada juga yang belum. kegiatan pelatihan ini dilaksanakan secara terjadwal. Pada setiap pertemuan (pelatihan), setiap peserta akan diberikan sosialisasi materi tentang komunikasi bisnis melalui pemanfaatan media sosial sebagai sarana 
pemasaran hasil produksi, mulai dari pengenalan pengenalan media sosial sampai dengan proses pemasaran produk, dan plus-minus teknologi internet. Di sisi lain, kepada setiap peserta akan diberikan softcpy seluruh bahan pelatihan, sehingga bisa dijadikan bahan acuan dan arsip kepada semua peserta pelatihan. Kepada para peserta yang telah dilatih, nantinya diharapkan dapat menyebarluaskan pengetahuan dan keterampilan yang telah dimilikinya kepada para UKM Keramik yang tidak dapat mengikuti pelatihan dengan program imbas. Melalui pelatihan ini, diharapkan para UKM yang ada di di Sentra Industri Keramik, Plered Kabupaten Purwakarta mampu memasarkan dan mempromosikan hasil produksinya dengan media sosial.

Metode pelaksanaan dalam program pengabdian kepada masyarakat meliputi tahapan: (a) studi pendahuluan, (b) pelatihan, (c) evaluasi . Perincian kegiatan di masingmasing tahapan diuraikan seperti berikut.

\section{Studi Pendahuluan}

Pada tahapan studi pendahuluan akan dilakukan kegiatan-kegiatan sebagai berikut:

1. Pengumpulan persoalan yang dihadapi para UKM yang berada di Sentra Industri Keramik, Plered, Kabupaten Purwakarta

2. Klasifikasi persoalan para UKM yang berada di Sentra Industri Keramik, Plered, Kabupaten Purwakarta dan pencocokan dengan potensi yang ada pada institusi.

3. Penyusunan skala prioritas program dengan mendasarkan pada peluang untuk diimplementasikan, ketersediaan sumber daya dan ketersediaan sumber daya dari tim pendamping,
4. penyusunan rencana kerja dan instrumen pelaksanaan program,

5. penetapan tim pelaksana dan uraian kerjanya sesuai kepakaran yang dimiliki,

6. Diskusi/pembekalan tim dalam hal pelaksanaan teknis.

\section{Pelaksanaan}

Pada tahapan pelaksanaan akan dilakukan kegiatan-kegiatan sebagai berikut:

1. Pembagian materi dalam bentuk softcopy dan hardcopy

2. Penjelasan umum tentang sistem pemasaran sosial

3. Pelatihan pemanfaatan meadia sosial sebagai Alat Komunikasi bisnis keramik

Pelaksanaan evaluasi dilakukan untuk dua tujuan yaitu: (a) umpan balik untuk perbaikan dini tahap pelaksanaan dan (b) umpan balik untuk pelatihan berikutnya. Ada dua modus pelaksanaan evalusi yang dilakukan. Modus pertama adalah dalam pelaksaan pelatihan dan modus kedua adalah di akhir pelaksanaan pelatihan. Modus pertama untuk tujuan evaluasi melakukan perbaikan dini dan modus kedua untuk perbaikan program berikutnya. Hasil pada tahapan evaluasi dijadikan dasar dalam menyusun laporan pelaksanaan program pengabdian, yang mencakup uraian pelaksanaan program, hambatanhambatan dalam pelaksanaan, capaian dari target yang ditetapkan dan solusi yang dilakukan dalam mengatasi hambatan. Pada akhirnya, laporan pelaksanaan program ini dijadikan dasar pertanggungjawaban pelaksanaan pengambdian kepada pihak-pihak yang berkepentingan. 


\section{Hasil Dan Pembahasan}

Kegiatan pelatihan pemanfaatan media sosial ini diikuti Adapun profil dari para UKM yang mengikuti pelatihan pemanfaatan media sosial sebagai sarana pemasaran prosuk adalah sebagai berikut

\section{Jenis Produk Keramik UKM Keramik di Sentra Industri Keramik Plered}

Pembuatan keramik Plered memang sudah berlangsung turun temurun dan diperkirakan dimulai sejak tahun 1904. Awalnya, masyarakat sekitar membuat keramik dari tanah liat merah dan termasuk gerabah ini untuk memenuhi perkakas rumah tangga. Tapi, pada perkembangannya kerajinan tersebut mampu menjadi sumber pendapatan tersendiri bagi masyarakat sekitar.

Setelah semakin berkembangnya teknologi dan informasi terjadi perubahan kebiasaan para perajin. Dulu umumnya perajin membuat keramik dari bahan baku tanah liat biasa. Sekarang, sebagian perajin yang memakai bahan baku tanah liat warna putih. Menurut mereka, ada kelebihan dan kekurangannya memakai bahan tanah liat putih yang telah dicampur dengan kaolin, pospat, dan kuarsa.

Menurut Mulyana, perajin lainnya, bahan baku tanah liat warna putih itu tidak terdapat di Purwakarta, tapi didatangkan dari Sukabumi. Keuntungannya, bahan dapat dicorkan ke dalam cetakan dengan motif beragam. Sedangkan bahan tanah liat biasa tidak bisa dicorkan ke dalam suatu cetakan. Hanya bisa diputar (dileler) untuk dibentuk suatu model. Dalam menciptakan berbagai motif atau model baru, Pemda Purwakarta melalui Deperindag telah membuat pusat penelitian dan pengembangan (Litbang) Keramik yang secara rutin mendatangkan ahli-ahli desain dari ITB, guna memberikan bimbingan. Menurut informasi dari Dinas Koperasi dan Usaha Kecil Menengah Purwakarta, dari ratusan perajin keramik hanya 40 perajin yang masuk menjadi anggota koperasi dengan nama "Sanggar Sentra

Keramik". Koperasi ini secara kontinyu mendapatkan order dari pusat perbelanjaan Sogo dan beberapa buyer dari luar negeri.

Plered terkenal dengan industri rumahan, atau home industry .. Yakni produksi gerabahnya, atau biasa dikenal orang dengan keramik Plered. Plered pun telah lama dikenal sebagai wilayah penghasil keramik. Berasal dari daerah ini, berbagai produksi bentuk dan ukuran keramik nan dihasilkan, berupa keramik bentuk kecil, sedang hingga besar. Dengan berbagai ukuran, aneka desain, motif dan cara pemrosesan,seperti tampak di bawah ini

Adapun berbagai produk dari industri keramik Plered nan cukup digemari masyarakat luas adalah: guci, celengan keramik, vas bunga, pot bunga, loka bakaran sate, loka bakaran jagung, loka bakaran dupa, loka stanggi menyan, wadah sabun, wadah odol dan sikat gigi, alas vas dan pot bunga, nampan keramik. Ada juga berbagai jenis terakota, berbagai jenis porselen, berbagai jenis tembikar dan gerabah bakar, serta tentu saja genting. Yang paling populer dan merebut hati para pecinta keramik, ialah tentu saja celengan keramik Plered, guci, serta genting Plered Purwakarta. Salah satu contoh yang dihasilkan UKM keramik seperti tampak di bawah ini
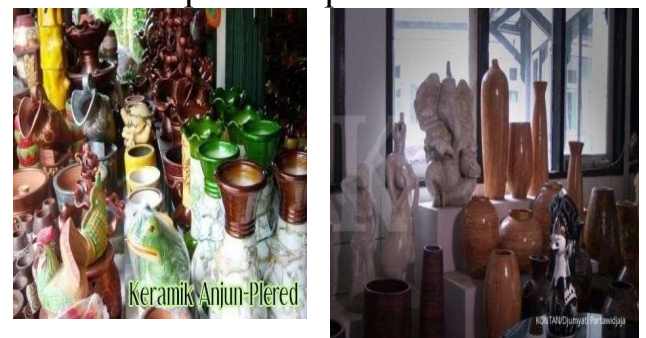

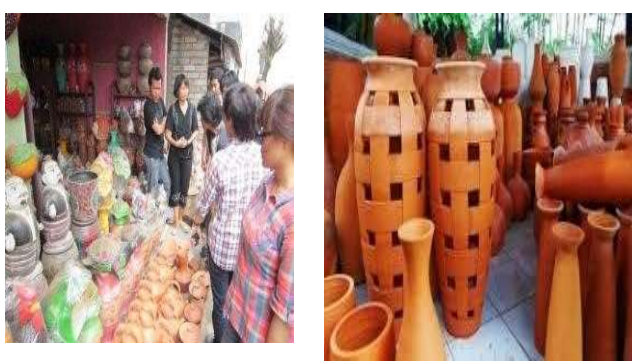

Gambar 2: Jenis Produk Keramik Sumber : Inovasi Baru Para Pengrajin

$\underline{\text { Keramik Plered » Purwakarta Post }}$

\section{Pemanfaatan Media Sosial sebagai alat Komunikasi bisnis}

Media social atau disebut juga media online telah mengalami perkembangan dan pengaruh yang luar biasa dalam pemanfaatannya dalam dusnia bisnis. Banyak pelaku bisnis memanfaatkan media social sebagai alat untuk melakukan komunikasi bisnis. Pesatnya perkembangan media sosial kini dikarenakan semua orang seperti bisa memiliki media sendiri. Jika untuk memiliki media tradisional seperti televisi, radio, atau koran dibutuhkan modal yang besar dan tenaga kerja yang banyak, maka lain halnya dengan media. Seorang pengguna media sosial bisa mengakses menggunakan media sosial dengan jaringan internet bahkan yang aksesnya lambat sekalipun, tanpa biaya besar, tanpa alat mahal dan dilakukan sendiri tanpa karyawan. Pengguna media sosial dengan bebas bisa mengedit, menambahkan, memodifikasi baik tulisan, gambar, video, grafis, dan berbagai model content lainnya.

Media sosial adalah mengenai menjadi manusia biasa. Manusia biasa yang saling membagi ide, bekerjasama, dan berkolaborasi untuk menciptakan kreasi, berpikir, berdebat, menemukan orang yang bisa menjadi teman baik, menemukan pasangan, dan membangun sebuah komunitas. Intinya, menggunakan media sosial menjadikan kita sebagai diri sendiri. Selain kecepatan informasi yang bisa diakses dalam hitungan detik, menjadi diri sendiri dalam media sosial adalah alasan mengapa media sosial berkembang pesat. Tak terkecuali, keinginan untuk aktualisasi diri dan kebutuhan menciptakan personal branding.

Banyak perusahaan membangun wadah sosial sendiri yang mencoba untuk menghubungkan blok bangunan tujuh fungsional sekitar merek mereka. . Ini adalah komunitas swasta yang melibatkan orang-orang di sekitar tema yang lebih sempit, seperti di sekitar panggilan tertentu, merek atau hobi, dari wadah media sosial seperti Facebook atau Google+.

Sementara jejaring sosial merupakan situs di mana setiap orang bisa membuat web page pribadi, kemudian terhubung dengan temanteman untuk berbagi informasi dan berkomunikasi. Jejaring sosial terbesar antara lain Facebook, Myspace, Plurk, dan Twitter. Jika media tradisional menggunakan media cetak dan media broadcast, maka media sosial menggunakan internet. Media sosial mengajak siapa saja yang tertarik untuk berpertisipasi dengan memberi kontribusi dan feedback secara terbuka, memberi komentar, serta membagi informasi dalam waktu yang cepat dan tak terbatas.

Saat teknologi internet dan mobile phone makin maju maka media sosial pun ikut tumbuh dengan pesat. Kini untuk mengakses facebook atau twitter misalnya, bisa dilakukan di mana saja dan kapan saja hanya dengan menggunakan sebuah mobile phone. Demikian cepatnya orang bisa mengakses media sosial mengakibatkan terjadinya fenomena besar terhadap arus informasi tidak hanya di negara-negara maju, tetapi juga di Indonesia. Karena kecepatannya 
media sosial juga mulai tampak menggantikan peranan media massa konvensional dalam menyebarkan berita-berita.

Berikut adalah contoh produk keramik yang dipasang di media social google

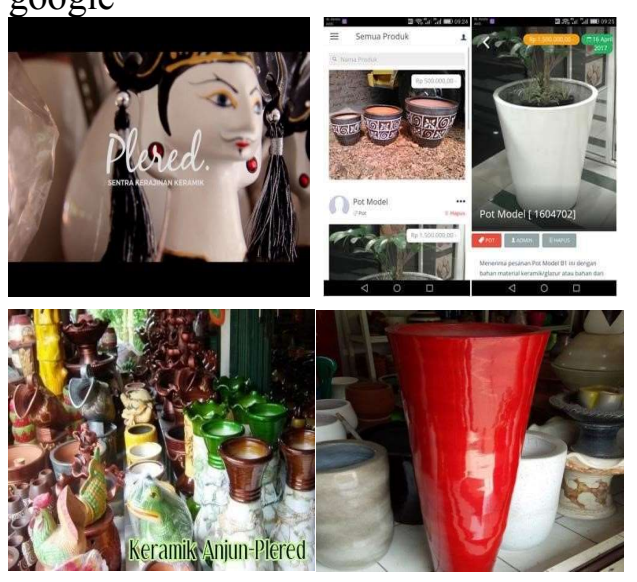

Gmabar 2 : Jenis Produk Keramik yang dipasang di google

Sumber: Inovasi Baru Para Pengrajin

$\underline{\text { Keramik Plered » Purwakarta Post }}$

Email salah satu Media Sosial

Dalam memasarkan produk keramik yang diproduksi para UKM keramik langkah awal dapat mengirimkan surat atau pesan elektronik sebagai bagian dari media sosial kepada konsumen atau pelanggan untuk menawarkan produk keramik karena saat ini, mengirim pesan via email merupakan salah satu cara yang paling efisien, cepat, dan murah. Sebenarnya cara kerja email ini cukup sederhana. Sama seperti ketika kita menulis surat kepada orang lain. Bedanya, dengan email kita bisa mengirim pesan lebih cepat dan dapat disertai dengan file tertentu yang ingin kita kirim juga. Berikut ini adalah proses cara kerja email secara singkat:

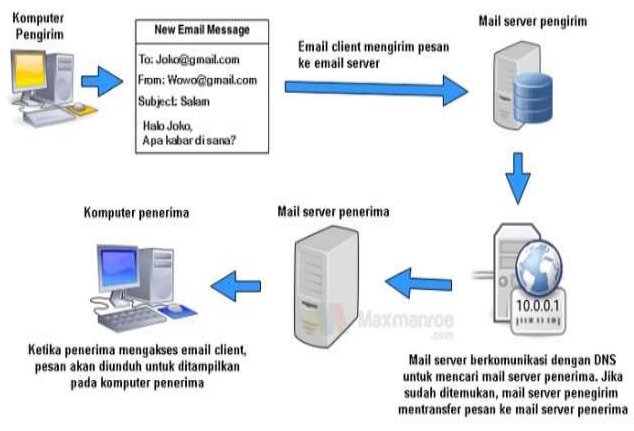

Gambar 3: cara kerja email

Sumber: https://www.google.co.id/

1. Pemilik email membuka emailnya dan kemudian menuliskan isi pesan yang akan dikirim.

2. Selanjutnya, pengguna email tersebut memberikan instruksi pada aplikasi email untuk mengirimkan pesan pada alamat email lainnya.

3. Email server akan mengidentifikasi alamat email tujuan, lalu mengirimkan pesan tersebut ke email server lain yang lokasinya dekat dengan alamat tujuan. Terkadang sebuah email dikirim melalui beberapa email server, tergantung rute yang dilaluinya.

4. Ketika pesan email terkirim ke alamat email penerima, maka isi pesan tersebut tersimpan di email server hingga si penerima membukanya.

5. Saat penerima membuka pesan di kotak pos/ inbox, maka aplikasi email penerima akan meminta email baru yang ada pada email server lalu mengunduhnya ke dalam komputer si penerima email. 
6. Selanjutnya, penerima email dapat melihat dan membaca isi pesan yang telah diunduh tadi.

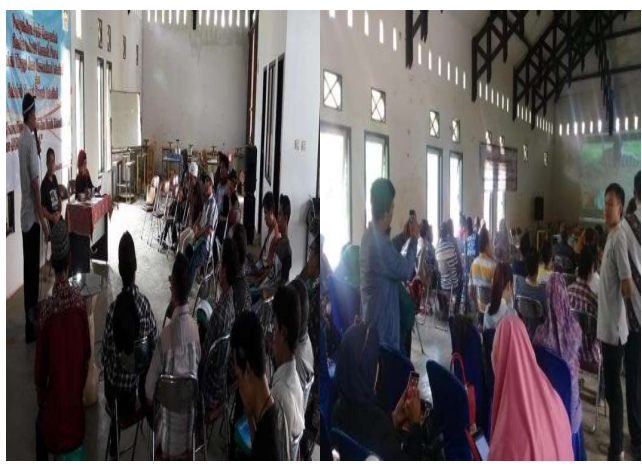

Gambar 4. Suasana pelatihan pemanfaatan media social untuk bisns dikalangan UKM Kermik

Komunikasi bisnis melaui media sosial saat ini banyak dilakukan dengan memanfaatkan email. Dan sebagian besar pebisnis sosial melakukan pemasaran melalui email untuk meningkatkan penjualan. Bisnis keramik melalui email merupakan salah satu pemasaran sosial yang paling tua. Dan hingga saat ini email marketing masih termasuk jenis pemasaran sosial yang sangat efektif.

Pentingnya mengelola media social bagi para UKM sebagaimana telah dikemukakan sebelulmya dalam perkembangan bisnis keramik yaitu diantaranya: pertama, mengenal pelanggan. Kedua, mendengar keinginan konsumen. Ketiga, memberikan respon cepat. Kelima, melihat persaingan di pasar. Keenam, meningkatkan pengunjung situs

Setelah program ini terlaksana, maka untuk mengukur tingkat keberhasilan dari keseluruhan rangkaian kegiatan tersebut, akan dilakukan evaluasi pada rentang proses dan akhir kegiatan, yaitu pada saat dilakukan pada akhir pelatihan, Kegiatan evaluasi ini akan melibatkan: ketua dan anggota pengabdian kepada masyarakat. Kriteria dan indikator pencapaian tujuan dan tolak ukur yang digunakan untuk menjustifikasi tingkat keberhasilan kegiatan dapat dijabarkan sebagai berikut:

Tabel 2. Kriteria dan indikator pencapaian tujuan dan tolak ukur yang digunakan untuk menjustifikasi tingkat keberhasilan kegiatan

\begin{tabular}{|c|c|c|c|c|c|}
\hline No & Jenis Data & $\begin{array}{l}\text { Sumber } \\
\text { Data }\end{array}$ & Indicator & $\begin{array}{l}\text { Kriteria } \\
\text { Keberhaslan }\end{array}$ & Instrument \\
\hline 1 & $\begin{array}{l}\text { Pengetahuan } \\
\text { Tentang } \\
\text { komunikasi } \\
\text { bisnis } \\
\text { Pengetahuan } \\
\text { tentang } \\
\text { internet/ } \\
\text { media } \\
\text { sosial dan } \\
\text { analisisnya }\end{array}$ & $\begin{array}{l}\text { peserta } \\
\text { pelatihan }\end{array}$ & $\begin{array}{l}\text { pengetahuan } \\
\text { para peserta } \\
\text { mengenai } \\
\text { komunikasi } \\
\text { bisnis, } \\
\text { komunikasi } \\
\text { antarbudaya, } \\
\text { media social } \\
\text { dan } \\
\text { publikasi, } \\
\text { hokum dan } \\
\text { etika serta } \\
\text { iklan di } \\
\text { media sosial }\end{array}$ & $\begin{array}{l}\text { Terjadinya } \\
\text { perubahan } \\
\text { Yang } \\
\text { Positif } \\
\text { terhadap } \\
\text { komunikasi } \\
\text { bisnis } \\
\text { melalui } \\
\text { media } \\
\text { sosial }\end{array}$ & $\begin{array}{l}\text { Pedoman } \\
\text { wawancara }\end{array}$ \\
\hline 2 & $\begin{array}{l}\text { keterampilan } \\
\text { peserta dalam } \\
\text { memanfaatkan } \\
\text { media sosial }\end{array}$ & $\begin{array}{l}\text { peserta } \\
\text { pelatihan }\end{array}$ & $\begin{array}{l}\text { keterampilan } \\
\text { para peserta }\end{array}$ & $\begin{array}{l}\text { Terjadinya } \\
\text { perubahan } \\
\text { yang } \\
\text { positif } \\
\text { terhadap } \\
\text { komunikasi } \\
\text { bisnis } \\
\text { dalam } \\
\text { menggunakan } \\
\text { computer }\end{array}$ & $\begin{array}{l}\text { observasi } \\
\text { pedoman } \\
\text { wawancara }\end{array}$ \\
\hline 3 & $\begin{array}{l}\text { kemampuan } \\
\text { dan } \\
\text { keterampilan } \\
\text { peserta } \\
\text { dalam } \\
\text { menggunakan } \\
\text { media sosial } \\
\text { sebagai alat } \\
\text { komunikasi } \\
\text { bisnis peserta }\end{array}$ & $\begin{array}{l}\text { peserta } \\
\text { pelatihan }\end{array}$ & $\begin{array}{l}\text { kemampuan } \\
\text { dan } \\
\text { keterampilan } \\
\text { peserta dalam } \\
\text { menggunakan } \\
\text { media social } \\
\text { sebagai alat } \\
\text { komunikasi } \\
\text { bisnis hasi } \\
\text { produk } \\
\text { keramik }\end{array}$ & $\begin{array}{l}\text { Terjadinya } \\
\text { perubahan } \\
\text { yang } \\
\text { kemamouan } \\
\text { dan } \\
\text { keterampilan } \\
\text { dalam } \\
\text { media } \\
\text { sosial } \\
\text { sebagai } \\
\text { alat } \\
\text { komunikasi } \\
\text { bisnis } \\
\text { produk } \\
\text { keramik }\end{array}$ & $\begin{array}{l}\text { pedoman } \\
\text { wawancara } \\
\text { dan format } \\
\text { observasi }\end{array}$ \\
\hline
\end{tabular}




\section{Kesimpulan dan Saran}

\section{Simpulan}

Berdasarkan analisis kegiatan tersebut dapat disimpulkan beberapa hal sebagai berikut:

1. Kegitan pengabdian pada masyarakat yang dilakukan ini sangat bermanfaat dalam meningkatkan pengetahuan peserta UKM keramik dalam memanfaatkan media sosial sebagai sarana pemasaran produk, sehingga memberikan peluang untuk memper luas pasar produk yang dapat berimbas pada peningkatan omset usaha.

2. Pengabdian pada masyarakat untuk para UKM keramik di Sentra Industri Keramik Plered, Kabupaten Purwakarta berupa sosialisasi dan pelatihan media sosial sebagai sarana pemasaran produk sangat perlu karena perkembangan era teknologi yang menuntut para pelaku usaha untuk bersaing secara global dengan media sosial.

\section{Saran}

Pada masa berikutnya, kegiatan pengabdian pada masyarakat ini tidak hanya dilakukan untuk para UKM keramik yang berada di sentra industry keramik, namun kegiatan pengabdian pada masyarakat berupa sosialisasi dan pelatiahan pemanfaatan media sosial sebagai serana komunikasi bisnia perlu dilakukan untuk para UKM keramik yang ada di luar kabupaten Purwakarta

\section{Daftar Pustaka}

Grant, August E \& Meadows, Jennifer H. (eds.) (2010).Communication Technology Update and
Fundamental.12th Edition.Boston: Focal Press

Kaplan, Andreas M.; Michael Haenlein (2010) "Users of the world, unite! The challenges and opportunities of Social Media". Business Horizons 53(1): 59-68.

Kietzmann, Jan H. (2011). "Social media? Get serious! Understanding the functional building blocks of social media". Business Horizons. 54 (3): 241-251.

doi:10.1016/i.bushor.2011.01.005. ISSN 00076813. Diakses tanggal 2011-08-23.

Utami, H. N. (2007). Keberdayaan, Kemajuan dan Keberlanjutan Usaha Pengrajin: Kasus Kabupaten Sidoarjo dan Kabupaten Magetan Provinsi Jawa Timur. Bogor: Institut Pertanian Bogor.

\section{Internet}

https://id.wikipedia.org/wiki/Media sosial https://www.google.co.id/

Inovasi Baru Para Pengrajin Keramik

Plered » Purwakarta Post

.https://alihamdan.id/komunikasi-bisnis/ https://www.google.com/search?q=profi

$\underline{1+\mathrm{UKM}+\text { keramik+Plered\&client }=\text { fir }}$ efoxb\&tbm $=$ isch \& tbo $=u \&$ source $=u$ niv\&sa $=$ X\&ved $=2$ ahUKEwjcp $4 O V$ k8LcAhVTeisKHRwiDGYQsA R6BAgDEAE\&biw $=1366 \&$ bih $=621$ \#imgrc=7BynOC5cShcubM: 